\title{
Effect of D-Mannose on Gene Expression of Neuraminidase Produced from Different Clinical Isolates of Pseudomonas aeruginosa
}

\author{
Zina Hashem Shehab ${ }^{1^{*}}$ \\ Bahaa Abdullah Laftaah AL-Rubaii ${ }^{2}$
}

Received 25/11/2018, Accepted 17/1/2019, Published 2/6/2019

This work is licensed under a Creative Commons Attribution 4.0 International License.

\begin{abstract}
:
The present work aimed to investigate the neuraminidase (nanl) gene expression in 32 different clinical isolates of Pseudomonas aeruginosa to explore the role of the enzyme in different types of infection and might give a better understanding of host cell-pathogens interaction. In addition, the effect of monosaccharide D-mannose on neuraminidase gene expression in eight isolates was studied by utilizing a reverse transcription-quantitative polymerase chain reaction (RT-qPCR). The results demonstrated that the highest expression of nanl gene was in otitis samples $(208,913.81)$ which were significantly higher than that from other infections $(\mathrm{P}<0.01)$. While, the concentrations of gene copies obtained from urine, sputum and burns samples were 93,535.34, 92,254.64 and 74,029.63respectively. While the least expression in wound samples $(32,017.06)$. This suggests that neuraminidase in ear samples might be more virulent and invasive followed by that from urine, sputum, burns and wounds samples. The considerable interest of addition Dmannose significantly reduced the rate of neuraminidase activity reached fivefold in some isolates. This indicates that D-mannose down regulates nanl gene expression. Hence, this sugar could be used in the development of potential new antibacterial agents where it acts as a competitive neuraminidase inhibitors.
\end{abstract}

Key words: D-mannose, Gene expression, Neuraminidase, Pseudomonas aeruginosa, RT-qPCR.

\section{Introduction:}

Pseudomonas aeruginosa is a Gramnegative rod-shaped bacterium which is ubiquitous in the ordinary environment, animals and humans. This bacterium is able to grow in the moisten positions and it succeeds to use a wide extent of organic compositions (1). Serious infections may be linked with high ratio of mortality in immunocompromised patients e.g. cancer, HIV and cystic fibrosis (CF). These infections often result in significant morbidity and mortality $(2,3)$. Also, this bacterium can lead to intense life-menacing infections in patients with (CF), endocarditis, skin injuries or artificial implants (4). The pathogenicity of $P$. aeruginosa is linked with different metabolic abilities, multiple mechanisms of resistance, and a large repertoire of virulence factors and adaptation, with gene expression is responsible of tightly organizing of all of these activities (5). Several mechanisms have been suggested for these actions, including increasing of a sialoglycolipid receptor numbers and beyond that is the possible augmentation of exposition to the bacterial enzyme,

${ }^{1}$ Department of Biology, College of Science for Women, University of Baghdad, Baghdad, Iraq

${ }^{2}$ Department of Biology, College of Science, University of Baghdad, Baghdad, Iraq

*Correspondence: zinahashem4@gmail.com neuraminidase (6).

This enzyme has ability to cleave terminal sialic acid (neuraminic acid) residues from many glycoconjugates expressed on host cells surface and have been correlated with pathogenesis of infectious diseases, bacterial nutrition and cellular interactions(7). Neuraminidases are widely distributed in nature, from viruses, and microorganisms such as bacteria, protozoa, and fungi to avian and mammalian species among the vertebrates, However, the enzymes are absent in plant, yeast, and insects (8). Neuraminidase is encoded by a gene called nanl that is responsible for adherence to the respiratory tract, and plays a significant role in bacterial attachment and subsequent invasion into the host cells, particularly into epithelial cells (9). $P$. aeruginosa neuraminidase (NanPs) production has been related to biofilm formation and lung colonization (10). Group of researchers observed that a catalytic pocket of neuraminidases are structurally analogous to canonical crystallographic analyses of $P$. aeruginosa neuraminidase, which has appeared to be more opened compared to others (11). Some investigators hypothesized that stimulation of neuraminidase production in pathogenic bacteria 
depends on the presence of macromolecular complexes like glycoprotein which may be considered as a way to adaptation and invading the host. That postulate is boosted by the specificity of bacterial neuraminidases toward one or different types of bonds in the substrate, whereas the hydrolysis rate is differed for the different substrates based on their molecular size and hydrophobic or hydrophilic character (12).Until recently there were very limited researches about the production of bacterial neuraminidase being as one of important virulence factors. Therefore, in the present study, we estimated the gene expression of neuraminidase gene nanl in different clinical isolates of $P$. aeruginosa by utilizing the real-time PCR based on Stephenson (13).He indicated that this technique is considered as a powerful tool to quantify gene expression genetically at accurate level, depending on the quantitative endpoint for real-time RT-PCR and the threshold cycle (CT). It is the first time in Iraq to display the level of diversity in gene expression of neuraminidase between different isolates sources, which may lead to different result of invasion. Additionally, there is a need for new therapeutic strategies to inhibit of bacterial neuraminidases by preventing bacterial infection through blocking the receptors of adherence by utilizing of D-mannose. This monosaccharide is used here as a new attempt for providing new competitive neuraminidase inhibitors that inhibits the neuraminidase activity in vitro. Thus, they represents as a potential new antibacterial agents.

\section{Materials and Methods:}

\section{Samples collection, Isolation and Identification:}

One hundred and twenty two different isolates were obtained from patients who visited as "out-patients" to Al Yarmouk, Al Kindi and Baghdad teaching hospitals at Baghdad city during March to August 2017. Different samples were streaked out onto MacConkey agar, blood agar and nutrient agar. The samples were further sub cultured onto Pseudomonas agar and Citrimide agar to obtain pure colonies, and 55 isolates suspected as $P$. aeruginosa. Those colonies were then checked with routine microscopic and biochemical tests to confirm identification. The isolates were incubated at $37{ }^{\circ} \mathrm{C}$ for $24 \mathrm{~h}$ and stored at $-80{ }^{\circ} \mathrm{C}$ in Brain Heart Infusion Broth (BHIB) containing 20\% (v/v) of glycerol (14). They were preserved at microbiology lab, Department of Biology, College of Science, University of Baghdad.

\section{RNA extraction of $P$. aeruginosa isolates:}

After the existence of nanl gene was detected in 55 clinical isolates of $P$. aeruginosa by PCR technique (15). 32 positive isolates of $P$. aeruginosa carrying nanl gene were subjected to RNA extraction from the pure broth culture of $P$. aeruginosa using TRIzolTM reagent (Thermo Scientific, USA). Quantus fluorimeter (Promega, USA) was utilized to reveal the concentricity of extracted RNA with a view to determine the suitability of samples for subsequent usage. $1 \mu 1$ from each RNA sample was mixed with $199 \mu$ of diluted quanty flour dye and incubated for $5 \mathrm{~min}$ at room temperature in dark place to detect RNA concentration values.

\section{Neuraminidase gene expression by absolute quantification using the standard curve:}

The nanl gene expression was determined by the reverse transcription-quantitative polymerase chain reaction (RT-qPCR) technique by absolute quantification using the standard curve. This includes, creating standard curve with genomic DNA (gDNA) templet. The standard curve method employs a dilution series of known template copy numbers in the qPCR assay. Linear regression of $\log$ concentration (copy $\mu^{-1}$ ) versus CT gives the standard curve, and then used to calculate template concentration (copy $\mu 1^{-1}$ ) of the sample. Seven of $0.2 \mathrm{ml}$ tubes were prepared, $90 \mu \mathrm{l}$ of nuclease free water was added to each tube then $10 \mu \mathrm{l}$ from sample of $46^{*} 10^{10}$ copy $\mu l^{-1}$ was added to the first tube. Serial dilution was performed by transferring $10 \mu \mathrm{l}$ from first tube to second tube and so on. The standard curve reaction started from the tube of $46^{*} 10^{7}$ copy $\mu 1^{-1}$ to the tube of $46^{*} 10^{3}$ copy $\mu \mathrm{l}^{-}$ ${ }^{1}$.After that we detected the samples expression by one step real-time PCR (RT-PCR) that was performed on a Mic qPCR Cycler (Bio Molecular System, Australia) using GoTag qPCR Master Mix GoTaq ${ }^{\circledR} 1-S t e p$ RT-qPCR System, (Promega, USA). Standard curve of neuraminidase was created with five-fold serial dilutions of one isolate of $P$. aeruginosa RNA extract from $46 \times 10^{3}$ to $46 \times 10^{7}$. The slope of the standard curve gives the amplification efficiency of a RT- PCR. According to the manufacturer's instructions, each reaction was composed of $10 \mu \mathrm{l}$ for each sample included: 5 $\mu \mathrm{l}$ qPCR Master Mix, $0.25 \mu \mathrm{l}$ of RT mix, $0.25 \mu \mathrm{l}$ of $\mathrm{MgCl} 2,0.5 \mu \mathrm{l}$ of each primer of virulence gene neuraminidase (nan 1$)$ using nanl-f 5'GGAGCGTGTTCCTGTGTGTATAG- ${ }^{\prime}$ and nanl$r$ 5'AGAAGA CGTCTCCCTGAATAAGA-3' (15), $2.5 \mu \mathrm{l}$ of nuclease free water and $1 \mu \mathrm{l}$ RNA template. The conditions for each cycle were $37{ }^{\circ} \mathrm{C}$ for 15 minutes to RT enzyme activation, $95{ }^{\circ} \mathrm{C}$ for $10 \mathrm{~min}$ for initial denaturation, followed by forty cycles of 
$95{ }^{\circ} \mathrm{C}$ though 30 seconds and $60{ }^{\circ} \mathrm{C}$ for 30 seconds. Subsequently, a melt on green curve analyses of 72$95^{\circ} \mathrm{C}$ at $0.3^{\circ} \mathrm{C} / \mathrm{sec}$ were performed $(13,16)$.

\section{Effect of D-Mannose on gene expression of neuraminidase: \\ The effect of D-Mannose (DIFCO} laboratories, Detroit, USA) on $P$. aeruginosa neuraminidase gene expression was achieved with eight randomly collected isolates. According to de Assis et al. method (17), our experiment was designed to depend only on the sugar concentration. Then, we designed our modification in the type of monosaccharide (D-mannose) and in the method of neuraminidase inhibition detection and as well as the estimation by relative real time PCR technique. Briefly, the experiment was performed by mixing 1 $\mathrm{ml}$ of fresh bacterial growth grown in (BHI) broth treated with $1 \mathrm{ml}$ of $(1 \mathrm{mM})$. Mannose was prepared by dissolving sugar in $80 \mathrm{mM}$ of sterilized PBS and incubated at room temperature for $30 \mathrm{~min}$. Then, incubation was stopped and RNA extraction was started for treated and non-treated D-Mannose samples (as control). Gene expression of neuraminidase was measured by the relative (RTqPCR) technique, as performed previously by One step real-time PCR using the following primer sets (18): oprD-f 5-TCCGCAGGTAGCACTCAGTTC3 and opr5`AAGCCGGATTCATAGGTGGTG-3` as a housekeeping gene was used to the normalizing gene, and the same set of new designed primer of neuraminidase nanl gene was used in gene expression of neuraminidase by absolute RT-qPCR. $(18,19)$

\section{Statistical Analyses:}

The Statistical Analysis System (SAS) was used to determine the difference of neuraminidase gene expression in different clinical isolates of $P$. aeruginosa. Then, Least significant difference LSD test and $T$ test were used to clarify the significant differences between treated and untreated isolates with D-mannose under probability levels of $<0.05$ and $<0.01(19)$.

\section{Results and Discussion:} Isolation and Identification:

A total of hundred and twenty two different nosocomial infection samples were obtained from patients whom visited several teaching hospitals in Baghdad city. All collected isolates were cultured on MacConkey agar, Blood agar, nutrient agar, Pseudomonas agar and Citrimide agar. In this study only fifty-five positive cultures were identified, which were from burn isolates $(n=21)$ assigned numbers from 1 to 21 ), bronchial wash isolates $(n=3)$ assigned from numbers (22 to 24$)$, sputum isolates $(n=7)$ from $(25$ to 31$)$, urine mid-stream isolates $(\mathrm{n}=5)$ from number ( 32 to 36 ), surgical wounds or abscesses isolates $(n=8)$ from number (37 to 44), otitis infection isolates (ear swabs) $(n=8)$ from number (45to 52 ), other samples in search were isolated; one for blood $(\mathrm{n}=1)$ with number (53), vaginal swab isolate $(\mathrm{n}=1)$ with number (54) and cerebrospinal cord fluid isolate $(\mathrm{CSF})(\mathrm{n}=1)$ with number (55).The colonies appears large flat and colorless on MacConkey agar because this pathogen is not fermenting lactose and with large flat colonies. However, when isolates were streaked on blood agar, they gave positive results that produced zones of beta-hemolysis with a grape like odor mucoid, pigmented colonies with distinguished metallic sheen. Then colonies were sub-cultured onto nutrient agar and most of them produce a diffusing green pigment in the agar (20). Next, these isolates were cultured on Pseudomonas agar on which all colonies showed growth with blue-green or brown pigmentation that is an indication for these bacteria (21). Finally, all isolates were cultured on nutrient agar where most of them gave a distinguished blue-green pigment. Isolation and identification of $P$. aeruginosa from other species of Pseudomonas were performed on Citrimide agar containing nalidixic acid, due to their resistance; Colonies were having ability to produce greenblue/yellow pigments when cultured on this agar, because citrimide acts as a detergent and inhibitor to the growth of other microorganisms. Therefore it is regarded as a selective differential medium. Such medium activates the production of pyocyanin and a fluorescent yellow-green pigment due to its iron content (22). A number of biochemical tests were performed in order to confirm the identification of the pure colonies. The tested organisms had a positive result for oxidase, catalase and growth at $42^{\circ} \mathrm{C}(20)$.

\section{Neuraminidase gene expression by absolute RT- qPCR:}

The virulence gene nanl expression among various isolates may give a better understanding of interaction between bacteria and host cell. They were examined with absolute real-time PCR by standard curve after overnight of incubation at $37^{\circ}$ $\mathrm{C}$ in (BHIB). The bacterial growth was compared with a standard suspension of McFarland tube 0.5 to obtain a microbial suspension at a concentration of $1.5 \times 10^{8}$ cell per $\mathrm{ml}$ to different clinical isolates of $P$. aeruginosa. The results were registered in Tables from 1 to 6 and indicated significant differences in the gene expression of nanl in different types of isolates under the probability level of $\mathrm{P}<0.01$.This was due to differences in the areas of infection, number of isolates as well as different physiological 
condition of patients. This difference led to a variation in the enzyme concentrations within each type of infection.

\begin{tabular}{ll}
\multicolumn{2}{l}{ Table 1. Nan1 copy numbers in burn samples } \\
\hline Isolate code & Gene copy no. \\
\hline 1 & $22,779.9$ \\
5 & $2,340.5$ \\
20 & $196,968.5$ \\
LSD value & $2667.83 * *$ \\
\hline$* *(\mathbf{P}<\mathbf{0 . 0 1})$ &
\end{tabular}

Table 2. Nan1 copy numbers in sputum samples

\begin{tabular}{ll}
\hline Isolate code & Gene copy no. \\
\hline 22 & $240,422.5$ \\
23 & $2,508.7$ \\
26 & $4,893.7$ \\
27 & $210,965.6$ \\
31 & $2,482.7$ \\
LSD value & $4187.72 * *$ \\
\hline$* *(\mathbf{P}<\mathbf{0 . 0 1})$ &
\end{tabular}

Table 3. Nan1 copy numbers in urine samples

\begin{tabular}{ll}
\hline Isolate code & Gene copy no. \\
\hline 32 & $2,562.7$ \\
33 & $105,375.9$ \\
34 & $3,180.7$ \\
35 & $2,639.8$ \\
36 & $353,917.6$ \\
LSD value & $4409.17 * *$ \\
\hline$* *(\mathbf{P}<\mathbf{0 . 0 1})$ &
\end{tabular}

Table 4. Nan1 copy numbers in wound samples

\begin{tabular}{ll}
\hline Isolate code & Gene copy no. \\
\hline 37 & $2,872.5$ \\
38 & $167,023.8$ \\
39 & $2,842.0$ \\
40 & $3,165.5$ \\
41 & $69,955.7$ \\
42 & $2,786.6$ \\
43 & $7,268.9$ \\
44 & 221.5 \\
LSD value & $7263.52 * *$ \\
** $(\mathbf{P}<\mathbf{0 . 0 1})$ &
\end{tabular}

Table 5. Nan1 copy numbers in otitis samples

\begin{tabular}{ll}
\hline Isolate code & Gene copy no. \\
\hline 45 & $567,763.3$ \\
46 & $23,692.8$ \\
47 & $230,397.4$ \\
48 & $122,569.5$ \\
49 & $113,582.9$ \\
50 & $511,609.6$ \\
51 & $98,291.2$ \\
52 & $3,403.8$ \\
LSD value & $11846.59 * *$ \\
\hline$* *(\mathbf{P}<\mathbf{0 . 0 1})$ &
\end{tabular}

Table 6. Nan1 copy numbers in different samples

\begin{tabular}{ll}
\hline Isolate code & Gene copy no. \\
\hline 53 & $295,587.2$ \\
54 & $3,692.5$ \\
55 & $3,608.5$ \\
LSD value & $4672.91 * *$ \\
\hline$* *(\mathbf{P}<\mathbf{0 . 0 1})$ &
\end{tabular}

Table 7 explained the rate of nanl gene copies in different groups of samples. They were correlated with types of infection and indicated significant differences under the probability level $(\mathrm{P}<0.01)$. The highest expression of gene was detected in otitis samples at 208,913.81, followed in descending order with the copy numbers $93,535.34$ to urine $92,254.64$ copy numbers to sputum, while the copy numbers of burns 74,029.63. Finally, a least expression in wounds samples 32,017.06. Nan1 gene was up-regulated in otitis samples with more than two fold copy numbers in urine and sputum samples and more than three folds gene expression to burns and wounds samples. While, the positive gene expression in the rare other types of isolates, showed high copy numbers of gene expression in blood sample $(295,587.2)$ followed by $3,692.5$ and $3,608.5$ copy numbers for the vaginal and CSF samples respectively.

Table 7. Rate of nan1 gene expression for different clinical isolates in different clinical isolates

\begin{tabular}{cc}
\hline Samples source & $\begin{array}{c}\text { Concentration rate of } \text { nan1 } \\
\text { gene expression }\end{array}$ \\
\hline Burns & $74,029.63$ \\
Sputum & $92,254.64$ \\
Urine & $93,535.34$ \\
Wound & $32,017.06$ \\
Ear & $208,913.81$ \\
LSD value & $1962.76 * *$ \\
\hline$* *(\mathbf{P}<\mathbf{0 . 0 1})$ &
\end{tabular}

A variety of glycosylated molecules with terminal sialic acid residues are presented in mucosal surfaces of mammals. Sialoglyco proteins in mucin participate have several important physical, immunological and antibacterial properties through effectively greasing, covering and defending epithelial surfaces. Sialic acid molecules play an important role in molecular mimicry to mammalian cell surface, nutrition as source of sugar and explaining cell to cell interactions through different metabolic mechanisms in great groups of mammalian pathogens and commensals. (23). Additionally, the prominent terminal sites of host sialic acids have made one of more extremely targeted carbohydrate receptors for bacterial adherence for more than a hundred model of sialic acid-binding agglutinins, 
adhesins and lectins between mammalian pathogens (24). Bacterial neuraminidases and their mucosal sialoglycan targets contributed to host-microbe interactions at every mammalian mucosal surface as in otitis media, which is a common and often recurrent bacterial infection. Bacterial neuraminidase can unmask implied ligands leading to exposure and adherence of host cells to bacterial toxins. This was identified at neutral $\mathrm{pH}$ in the middle ear fluids from patients with otitis media associated with effusion. The researchers observed that the plasma of patient lacked neuraminidase activity, indicating that neuraminidase in the middle ear fluid originated in the middle ear and was not transudate from blood. Since, mammalian neuraminidase has optimal activity near $\mathrm{pH} \mathrm{4}$. So, the authors concluded that microorganisms were the source of neuraminidase (25). As for the nanl expression in UTI samples, it may be attributed to the observation that high mortality in hospitalized patients is correlated with $P$. aeruginosa, this expression increases in people with intense comorbidity such as chronic renal failure, advanced liver disease or diabetes mellitus. Inappropriate antibiotic treatment is connected with poor results, which indicates the importance of adjusting experimental antibiotic treatment according to the microbiological susceptibility results (26). The researchers observed oligosaccharide chains in the glycoproteins of the urinary epithelium of pig bladder. These oligosaccharide chains were analogous to those oligosaccharide of human urinary epithelium mucin that has neuraminic acid acting as a substrate to neuraminidase, which is necessary in cell adherence and immunological operations (27). Regarding sputum samples, the human air passage encoded multiple neuraminidaselike enzymes. Some evidence suggested that $P$. aeruginosa neuraminidase facilitates bacterial association with the lung epithelium (6). A group of researchers hypothesized that the host cells react with flagellar protein of $P$. aeruginosa, leading to recruitment of the human neuraminidase by increasing liberation of mucin through activated muc1 gene from the epithelial cell surface. This way, it facilitates a cryptic binding site on mucin epidermal cells to flagellin binding and increasing $P$. aeruginosa adhesion to the airway epithelium due to removal of sialic acid residues from the extracellular cell surface protein mucin. On the other hand, human sialidase controls the epidermal cell mucin (muc1) by rising cleaving and shedding mucin from cell surfaces and blocking $P$. aeruginosa adhesion to airway cell associated epidermal cells. It is enticing to suppose that the balance between these opposite processes which include $P$. aeruginosa adherence versus decoy receptor function $(28,29)$. However, other studies found that $P$. aeruginosa neuraminidase was 1000 fold more active than the Clostridium perfringens enzyme in releasing neuraminic acid from respiratory epithelial cells (30). As for the genetic expression of neuraminidase for both wounds and burns, a neuraminic acid commonly was found at the outermost position of glycan chains at the surface of most mammalian cells (31). Commonly, the end of the O-linked oligosaccharide is linked to sialic acid in humans found that $\mathrm{N}$-acetyl neuraminic acid in surface on red blood cells (32). The negative charge of RBC membrane comes from the presence of $\mathrm{N}$-acetyl neuraminic acid which account for 74-94\% (33). These acids control the morphology, membrane deformation, oxidation capacity, RBC aging and even the construction and distribution of hemoglobin molecules in human RBCs (34). Interestingly, vaginal excretions with normal healthy flora generally consist of lactobacilli, do not show neuraminidase activity. Whereas, infected women with bacterial vaginitis have elevated activity of neuraminidase in vaginal fluids that is possible to be bacterial origin (35). Hence, permanence of neuraminidase -producing vaginal bacteria in enough numbers to rise vaginal fluid neuraminidase activity may be a risk factor for subclinical intrauterine infection and preterm delivery.(36) Sadula et al. (37) showed higher levels of sialic acid and aspartate transaminase (AST) levels in cerebrospinal fluid have been described in pyogenic meningitis (PM) as compared to tubercular meningitis (TBM). The neuraminic acids are among the most predominant molecules at the host-microbe surfaces. The varied types of neuraminic acids ease cell to molecule interactions through direct or indirect cell signaling including siglec-sialoglycoconjugate reactions (38). Additionally, structural evolution of neuraminic acids is analogous in various types of microorganisms and thus is seen as an arms racing between and within species (23). We can conclude from the above information, that the variations of nanl gene expression in different clinical isolates could be associated with the variable amount of sialic acid in host cell surface glycoconjugates, where, host sialic acid up regulates the secretion of neuraminidase from $P$. aeruginosa as a specific substrate to the enzyme ,according to the type of infected tissues.

\section{Effect of D-Mannose on gene expression of neuraminidase:}

There is a necessity for alternative curative strategies against $P$. aeruginosa due to the growing problem of prevalence of new resistant strains (39). It is important to find inhibitors targeting the $P$. 
aeruginosa neuraminidase to prevent infection because of its role in colonization (10). This enzyme offers an attractive target for therapeutic intervention (40). The data in Table 8 revealed the effect of the monosaccharide D-mannose through inhibition of neuraminidase production between 0.1 in isolate no.41 to 0.9 in isolate no. 20 when compared with the control isolate, which significant differences under the probability level of $\mathrm{P}<0.05$. We also found that D-mannose effectively and competitively inhibited neuraminidase expression by occupying the binding site of the enzyme active site's pocket. Therefore, we believe that a neuraminidase inhibitor to the respiratory tract infection can be used as a prophylactic agent against microbial pneumonia after the influenza virus infection and also in populations at risk (41). Our results agreed with de Assis et al. (17) who used Dgalactose as one of monosaccharides to neuraminidase inhibition by heamagglutination assay, Nevertheless, we used D-mannose instead with manipulation in the procedure to measure the change in neuraminidase production by relative RTPCR as quantitative assay, with the aim of obtaining new competitive neuraminidase inhibitors. The sugar suppressed bacterial growth and may thus represent a potential new antibacterial agent.

Table 8. Gene expression of nan1 in different clinical isolates of $P$. aeruginosa in the presence of D-mannose by relative real time PCR.

\begin{tabular}{cccc}
\hline $\begin{array}{c}\text { Isolate } \\
\text { code }\end{array}$ & $\begin{array}{c}\text { Fold change } \\
\text { without } \\
\text { treatment }\end{array}$ & $\begin{array}{c}\text { Fold change } \\
\text { with } \\
\text { treatment }\end{array}$ & T-Test \\
\hline 1 & 1.0 & 0.5 & $0.416^{*}$ \\
20 & 1.0 & 0.9 & $\mathrm{NS}$ \\
31 & 1.0 & 0.6 & $\mathrm{NS}$ \\
33 & 1.0 & 0.3 & $0.468^{*}$ \\
41 & 1.0 & 0.1 & $0.542^{*}$ \\
48 & 1.0 & 0.3 & $0.468^{*}$ \\
54 & 1.0 & 0.5 & $0.416^{*}$ \\
55 & 1.0 & 0.4 & $0.437^{*}$ \\
Mean & 1.0 & 0.45 & $0.419^{*}$ \\
LSD & $\mathrm{NS}$ & $0.469 *$ & -- \\
value & & &
\end{tabular}

In conclusion, an up-regulation of nanl gene expression was observed in otitis samples, by approximately more than two fold copy numbers in urine and sputum samples expression and more than three folds to burns and wounds sample compared with control. The impact of D-mannose was more pronounced in down-regulation of nanl gene, which implies that it can be used as a neuraminidase inhibitor.

\section{Acknowledgment:}

This work was supported by Biology department, College of Science University of Baghdad and the kind help and cooperation of $\mathrm{Al}$ Yarmouk, Al Kindi and Baghdad teaching hospitals at Baghdad city.

\section{Conflicts of Interest: None.}

\section{References:}

1. Pires DP, Silva S, Almeida C, Henriques M, Anderson EM, LamJS, etal.Evaluation of the ability of $C$. albicans to form biofilm in the presence of phage-resistant phenotypes of $P$. aeruginosa. Biofouling, 2013 Sep;29(10), 1169-80.

2. Smith DJ, Anderson GJ, Bell SC, Reid DW. Elevated metal concentrations in the CF airway correlate with cellular injury and disease severity. J Cyst Fibros.2014 Dec; 13:289-295.

3. Schurek KN, Breidenstein EBM, Hancock REW. Pseudomonas aeruginosa: a persistent pathogen in cystic fibrosis and hospital-associated infections, In: antibiotic discovery and development, Dougherty TJ and Pucci MJ (eds.), 2012; 1: 679-715.springer

4. Manita G M, King MM, Williamson KS, PérezOsorio AC, Akiyama $\mathrm{T}$, Khanam S, et al. The Pseudomonas aeruginosa PAO1 Two-Component Regulator CarSR Regulates Calcium Homeostasis and Calcium-Induced Virulence Factor Production through Its Regulatory Targets CarO and CarP , J Bact.2016 Jan ; 198 (6):951-963.

5. Silby MW, Winstanley C, Godfrey SA, Levy SB, Jackson RW. Pseudomonas Genomes: diverse and adaptable. FEMS Microbiol Rev, 2011 Jul; 35: 652680 .

6. Davies J, Dewar A, Bush AT, Gruenert T, Geddes $\mathrm{DM}$, Alton EW. Reduction in the adherence of Pseudomonas aeruginosa to native cystic fibrosis epithelium with anti-asialoGM1 antibody and neuraminidase inhibition. Eur Respir J., 1999 Mar; 13: 565-570.

7. Vimr RE. Unified theory of bacterial Sialometabolism: how and why bacteria metabolize host sialic acid (review article). ISRN Microbio, 2013 Sep: 26.

8. Lillehoj EP ,Hyun SW, Feng C, Zhang L ,Liu A ,Guang W, et al . NEU1 Sialidase Expressed in Human Airway Epithelia Regulates Epidermal Growth Factor Receptor (EGFR) and MUC1 Protein Signaling. J Biol Chem, 2012Mar; 287(11): 8214 8231.

9. Bradbury RS, Roddam LF, Merritt A, Reid DW, Champion AC. Virulence gene distribution in clinical, nosocomial and environmental isolates of Pseudomonas aeruginosa. J. Med. Microbiol.2010 Aug; 59(8):881-90.

10. Héry-Arnaud G , Nowak E, Caillon J, David V, Dirou A, Revert K, et al. Evaluation of quantitative PCR for early diagnosis of Pseudomonas aeruginosa infection in cystic. Clin Microbial Infect, 2017Mar; 23(3):203-207. 
13. Singleton RJ, Hennessy TW, Bulkow LR, Hammitt LL, Zulz T, Hurlburt DA, et al. Invasive pneumococcal disease caused by non-vaccine serotypes among Alaska native children with high levels of 7-valent pneumococcal conjugate vaccine coverage. JAMA, 2007Apr; 297:1784-1792.

14. Eneva R , Engibarov S , Abrashev I. Presence of NAcetylneuraminate Pyruvate-Lyase Activity in Sialidase Producing Strains of Erysipelothrix rhusiopathiae and Oerskovia sp. Acta microbiologica Bulgarica ,2016 Jan: 81-84

15.13 - Stephenson FH .Chapter 9 Real-Time PCR.In: Calculations for Molecular Biology and Biotechnology. $3^{\text {rd }}$ (ed.) Elsevier, 2016 Jun: 215-320.

16. Tille PM .Bailey \& Scott's diagnostic microbiology. 14th (ed.),2017:1084 Elsevier.

17. Shehab ZH, Laftah BA. Correlation of nan1 (Neuraminidase) and production of some type III secretion system in clinical isolates of Pseudomonas aeruginosa. Bio Sci Res, 2018Sep; 15(3):1729-1738.

18. Roche Molecular Systems, Inc. and F. Hoffmann-La Roche Ltd. Creating Standard Curves with Genomic DNA or Plasmid DNA Templates for Use in Quantitative PCR .Applied Biosystems. USA, 2003:1-9.

19. de Assis PR, Nakano V, Senhorinho GNA, AvilaCampos MJ. The use of a rapid assay to detect the neuraminidase production in oral Porphyromonas spp. isolated from dogs and humans .Journal of Microbiological Methods ,2013 Jun;94 : 159-160. Elsevier

20. Kolayli F, Karadenizli A, Savli H, Ergen K, et al. Effect of carbapenems on the transcriptional expression of the oprD, oprM and oprN genes in Pseudomonas aeruginosa.. J. Med. Microbiol. 2004 May; 53: 915-920.

21.SAS. Statistical Analysis System, User's Guide. Statistical version $9.1^{\text {th }}$ (ed.) SAS., 2012; Inst. Inc. Cary. NC, USA. 20- Mukherjee KL, Ghosh S (Eds.). Medical Laboratory Technology: Procedure Manual for Routine Diagnostic Tests, $2^{\text {nd }}$ (ed.), Tata McGraw Hill, New Delhi. 2010 Nov; 2: 596.

22. Anderson C, Johnson TR, Case CL, Cappuccino JG, Sherman N. Great Adventures in the microbiology laboratory $\left(8^{\text {th }}\right.$ ed). Pearson Custom Publishing. 2015May: 175-176.

23. Markey BK, Leonard FC, Archambault M, Cullinane A , Maguire D. Clinical veterinary microbiology. $2^{\text {nd }}$ (ed.) Elsevier, 2013 Oct: 875.

24. Angata T, Varki A. Chemical Diversity in the Sialic Acids and Related $\alpha$-Keto Acids: An Evolutionary Perspective. Chem Rev, 2002Feb; 102 (2):439-470.

25. Lewis AL, Lewis WG. Host sialoglycans and bacterial sialidases: a mucosal perspective. Cellular Microbiology, 2012 Aug; 14(8):1174-1182.

26. Klein JO, Bluestone CD. Otitis media in the infants and children. $4^{\text {th }}$ (ed.), 2007: 469.

27. Ferreiro JLL, Otero JAA, GonzaÂlez LG, Amazares LV, Blanco AA, Sanjurjo JRB, et al. Pseudomonas aeruginosa urinary tract infections in hospitalized patients: Mortality and prognostic factors. PLOS ONE, 2017May: 1-13.
28. Mastrodonato M, Mentino D, Lopedota A, Cutrignelli A, Scillitani G. A histochemical approach to glycan diversity in the urothelium of pig urinary bladder. Micros Res Tech, 2017 Nov; 80(2): 239-249.

29. Lillehoj EP, Hyun SW, Liu A, Guang W, Verceles $\mathrm{AC}$, Irina $\mathrm{G}$, et al. NEU1 Sialidase regulates membrane-tethered Mucin (MUC1) ectodomain Adhesiveness for Pseudomonas aeruginosa and decoy receptor release. J Biol Chem, 2015 Jul; 290(30): 18316-18331.

30. Lillehoj EP, Verceles AC, Goldblum SE. MUC1 decoy peptides for treatment and prevention of bacterial infections .Patent application publication, 2017 Nov: 1-30.

31. Cacalano G, Kays M, Saiman L, Prince A. Production of the Pseudomonas aeruginosa neuraminidase is increased under hyperosmolar conditions and is regulated by genes involved in alginate expression. J Clin Investig, 1992 Jun; 89:1866-1874.

32. Bergfeld AK, Samraj AN, Varki A. Metabolism of $N$ Glycolyl neuraminic acid in human and Non-human cells and potential relationships to human Disease. In: Taniguchi N., Endo T., Hart G., Seeberger P., Wong CH. (eds) Glycoscience: Biology and Medicine, 2015 Oct :1311-18. Springer, Tokyo

33. Aoki TA. comprehensive review of our current understanding of red blood cell (RBC) glycoproteins. Membranes, 2017 Sep; 7(56):1-10.

34. Huang Y, Tuo W, Di Wang D, Kang L, Chen X, Luo M. Restoring the youth of aged red blood cells and extending their lifespan in circulation by remodeling membrane sialic acid. J. Cell. Mol Med, 2016 Feb; 20(2) : 294-301

35. Huang YX, Wu ZJ, Mehrishi J. Human red blood cell aging: correlative changes in surface charge and cell properties. J Cell Mol Med, 2011 Dec; 15: 2634-42.

36. Briselden AM, Moncla BJ, Stevens CE, Hillier SL. Sialidases (neuraminidases) in bacterial vaginosis and bacterial vaginosis-associated micro flora. J Clin Microbiol,1992 Mar ;30: 663-666.

37. McGregor JA ,French JI, Jones MSW, Milligan K, Mc Kinney PJ, Patterson E, et al. Bacterial vaginosis is associated with prematurity and vaginal fluid mucinase and sialidase: Results of a controlled trial of topical clindamycin cream. Gynecology, 1994; Apr;170(4): 1048-1060.

38. Sadula SR, Vani N , Sailusha S. Study of Free Sialic Acid and Aspartate Transaminase Levels In Cerebrospinal Fluid of Patients With Pyogenic Meningitis and Tuberculosis. Journal of Biotechnology and Biochemistry, 2017 Nov; 3(6):1721.

39. McDonald ND, Lubin JB, Chowdhury N, Boyd EF. Host-Derived Sialic Acids Are an Important Nutrient Source Required for Optimal Bacterial Fitness In vivo. mBio, 2016Apr; 7(2):1-10.

40. Holmes AH, Luke SP, Moore MPH, Sundsfjord A , Steinbakk M, Regmi S, et al. Understanding the mechanisms and drivers of antimicrobial resistance. The Lancet, 2016Jan, 387(10014): 176-187. Elsevier Ltd

41. Hsiao YS, Parker D, Ratner AJ, Prince A, Tong L. Crystal structures of respiratory pathogen 


\section{تاثير ديـ مانوز على التعبير الجيني للنيورامينيديز المنتج من بعض العزلات السريرية لبكتريا Pseudomonas aeruginosa}

بهاء عبدالله لقته الربيعي2
زينة هاشم شهاب

21 قسم علوم الحياة، كلية العلوم لللبنات، جامعة بغداد، بغداد، العراق.

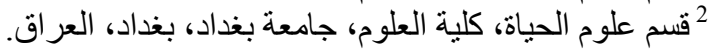

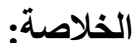

هدفت الدراسـة الحاليـة الـى التحري عن التعبيـر الجيني لانزيم النيور امينيداز Pseudomonas aeruginosa

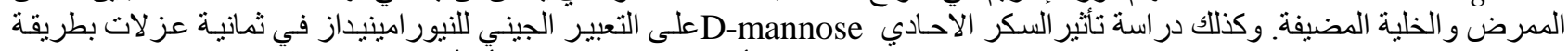

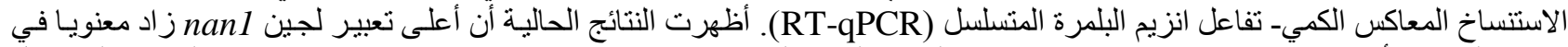

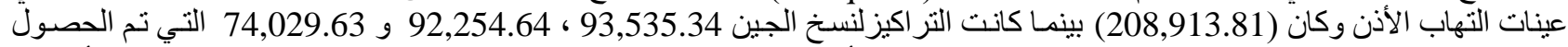

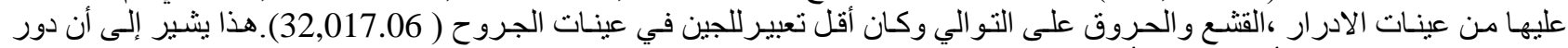

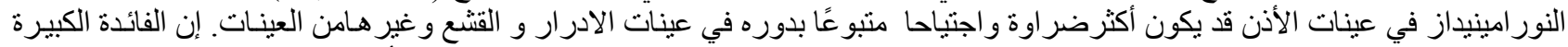

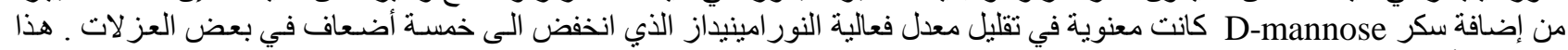

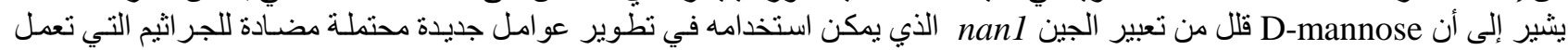
كمثبطات تنافسية للنيور امينيديز.

RT-qPCR ، الكلمات المفتاحية: ديـ مانوز، نعبيير جيني، نيور امينيديز، بكتريا الزوائف الزنجارية 